\title{
Introduction of life cycle assessment and sustainability concepts in chemical engineering curricula
}

DOI:

10.1108/IJSHE-09-2017-0146

\section{Document Version}

Accepted author manuscript

Link to publication record in Manchester Research Explorer

\section{Citation for published version (APA):}

Gallego Schmid, A., Schmidt Rivera, X. C., \& Stamford, L. (2018). Introduction of life cycle assessment and sustainability concepts in chemical engineering curricula. International Journal of Sustainability in Higher Education. https://doi.org/10.1108/lJSHE-09-2017-0146

\section{Published in:}

International Journal of Sustainability in Higher Education

\section{Citing this paper}

Please note that where the full-text provided on Manchester Research Explorer is the Author Accepted Manuscript or Proof version this may differ from the final Published version. If citing, it is advised that you check and use the publisher's definitive version.

\section{General rights}

Copyright and moral rights for the publications made accessible in the Research Explorer are retained by the authors and/or other copyright owners and it is a condition of accessing publications that users recognise and abide by the legal requirements associated with these rights.

\section{Takedown policy}

If you believe that this document breaches copyright please refer to the University of Manchester's Takedown Procedures [http://man.ac.uk/04Y6Bo] or contact uml.scholarlycommunications@manchester.ac.uk providing relevant details, so we can investigate your claim.

\section{OPEN ACCESS}


2 emerald International Journal of Sustainability in Higher Education

\section{Introduction of life cycle assessment and sustainability concepts in chemical engineering curricula}

\begin{tabular}{|r|l|}
\hline Journal: & International Journal of Sustainability in Higher Education \\
\hline Manuscript ID & IJSHE-09-2017-0146.R2 \\
\hline Manuscript Type: & Research Paper \\
\hline Keywords: & $\begin{array}{l}\text { sustainable pedagogy, carbon footprint, education, teaching LCA, } \\
\text { employability, key transferable skills }\end{array}$ \\
\hline \multicolumn{2}{|l}{} \\
\hline
\end{tabular}

\section{SCHOLARONE ${ }^{\text {Mx }}$ \\ Manuscripts}


Introduction of life cycle assessment and sustainability concepts in chemical engineering curricula

Alejandro Gallego-Schmid, Ximena C. Schmidt Rivera, Laurence Stamford

Sustainable Industrial Systems, School of Chemical Engineering and Analytical Science, The University of Manchester, The Mill, Sackville Street, Manchester M13 9PL, UK

(*) Corresponding author: alejandro.gallegoschmid@manchester.ac.uk

Keywords: sustainable pedagogy; carbon footprint; education; key transferable skills; employability; teaching LCA.

Submitted: 06-Sep-2017

Revised: 16-Nov-2017

\begin{abstract}
Purpose: The implementation of life cycle assessment (LCA) and carbon footprinting represents an important professional and research opportunity for chemical engineers, but this is not broadly reflected in chemical engineering curricula worldwide. This study presents the implementation of a coursework that is easy to apply, free of cost, valid worldwide and flexible enough to cover such holistic topics.
\end{abstract}

Design/methodology/approach: An analysis of chemical engineering curricula worldwide, a literature review and the implementation of a coursework case study are detailed. The latter combines practical exercises using free LCA software, oral presentations and debates.

Findings: The coursework goes beyond the calculation of results, giving the students key transferable skills to increase their employability like the capacity to negotiate/discuss in groups, software learning and development of critical thinking. The course is affordable and flexible, enabling adaptation to different sectors and engineering schools. One limitation is 
the challenge of ensuring robustness and consistency in marking, but this has been already improved with a more explicit rubric. The feedback of the students confirms these findings, including the learning of transferable skills as the major advantage.

Originality: This paper addresses, for the first time, the current state of 'life cycle thinking' teaching in the curricula of the top 25 chemical engineering schools worldwide, a literature review of previous experience, and a description of a novel coursework taking a theoretical and practical approach to LCA, carbon footprinting and socio-economic sustainability via free software and a comprehensive range of didactic activities.

\section{Introduction}

Sustainable development was defined in 1987 as "development that meets the needs of the present without compromising the ability of future generations to meet their own needs" (WCDE, 1987). This concept has evolved during recent years and, nowadays, sustainable development and sustainability involve the integration of environmental, social, and economic concerns into all aspects of decision-making processes (Emas, 2015). In parallel, the study of sustainable processes has evolved from an exclusively production-oriented analysis to a more comprehensive life cycle thinking approach where all the stages of the life of a product are assessed (e.g. raw materials extraction, transport, production, use and end of life). The fusion of the concepts of sustainability and life cycle thinking has resulted in the development and use of three different tools for assessing the environmental (life cycle assessment, LCA), economic (life cycle cost, LCC) and social aspects (social life cycle assessment, S-LCA).

According to ISO 14040 (2016), LCA is defined as the "compilation and evaluation of the inputs, outputs and the potential environmental impacts of a product system throughout its life cycle". LCA can include a comprehensive set of potential impacts affecting air, water and 
terrestrial ecosystems, and human health. The most common application of LCA is a narrow analysis that only accounts for greenhouse gases (GHG) and their impact on climate change, otherwise known as carbon footprinting. Carbon footprinting has taken an important position industrially and in the public sphere, gaining its own dedicated frameworks: ISO 14067 (2013) at international level, and national options like BSI PAS 2050 (2011) from the UK, which focusses on helping industries and service providers to assess their own carbon footprint. Additionally, new regulations have been defined for the declaration of product environmental impacts, such as ISO 14025 (2006) - Environmental Product Declaration (EPD) - and other more specific examples like Product Category Rules (PCR) for the construction sector (BSI EN 15804 (2012)).

With all these new regulations emplaced, it is almost imperative to prepare future professionals for these new challenges; especially when this would increase their employability. The increasing international statements of intent, such as the Paris climate change agreement, and the increasing commitment towards low carbon economies, have created new job opportunities in the cross-disciplinary field of 'green jobs', which nowadays focuses not only on environmental consultancy and waste management but also low-carbon energy and transport systems (e.g. renewables, energy efficiency, green fuels), carbon finance and climate change consultancy (Bird and Lawton, 2009). In these new circumstances, the role and opportunities for engineers are vast, being highlighted by different entities from governments to NGOs (HM Government, 2009). However, one of the major problems to cover these new vacancies is the lack of job-specific skills in Science, Technology, Engineering and Maths (STEM) and other related careers (Bird and Lawton, 2009). Despite the fact that recent literature has demonstrated the difficulties of analysing the impact of green jobs on the economy (Bowen and Kuralbayeva, 2015), recent figures have suggested that the low-carbon economy represents $2 \%$ of UK GDP and is expected to grow to $13 \%$ by 2050 
(The Guardian, 2017). Hence, it is highly likely that the employability rate of engineers will increase in conjunction with environmental skills-training.

More specifically, among all engineers, the possibilities of chemical engineers are growing in a field like sustainability as it requires multidisciplinary skills. Chemical engineering deals with "the design, construction, and operation of processes and chemical plants for the conversion of raw materials into useful products on an industrial scale" (Schaschke, 2014). The focus on design and process within chemical engineering, together with a strong safety and environmental remit, has increased interest in environmental sustainability and LCA/carbon footprinting such that the chemical engineering community now considers them important skills areas to develop in future professionals (Hall and Howe, 2010). In the case of research areas, these concepts have been either introduced to key research lines or even developed as stand-alone core themes. However, it is still unclear how this growing interest is reflected in the syllabus of chemical engineering courses in universities around the world.

In an effort to elucidate this matter, this paper first analyses how sustainability - specifically LCA and carbon footprint - has been included in the curriculum of the top 25 chemical engineering schools of universities around the world. Further, to assess evidence of how these concepts have been addressed, a literature review is carried out analysing teaching-focused publications that demonstrate the inclusion of LCA and carbon footprinting concepts in chemical engineering curricula. Finally, this paper presents a detailed description of a pedagogic proposal to incorporate these concepts in one of the top 25 chemical engineering schools, analysing the outcomes of the coursework and the benefits towards improving employability and non-technical skills. The main advantages and challenges of this proposal are analysed, including the students' feedback, as well as, the opportunities to adapt this example in other engineering schools' curricula. 


\section{Sustainability, LCA and carbon footprint in current chemical engineering curricula}

The presence of sustainability concepts, in particular of LCA and carbon footprint, in chemical engineering courses have been analysed across the top 25 chemical engineering schools in the World (QS, 2017). This was achieved by searching for terms like 'environmental engineering', 'sustainability', 'carbon footprint' and 'life cycle assessment' on the websites of the 25 top universities. Specifically, these concepts were sought in the description of the mission of the school, the definition of the role of a chemical engineer, the course contents for chemical engineering courses and research areas. If any of the terms were found, the context was analysed to see if the university covers these topics in their mission statement, courses, and research areas or when defining the role of a chemical engineer.

From the top 25 chemical engineering schools, 22 (88\%) have research areas directly related to sustainability and/or environmental engineering and $10(40 \%)$ have research groups with a focus on LCA and carbon footprinting. Furthermore, $17(68 \%)$ of the schools include sustainability and/or environmental engineering when mentioning their 'mission' and/or when defining the future role of a chemical engineers. Most of the schools, 16 (64\%), offer teaching modules related to sustainability and/or environmental engineering, but only 5 schools (20\%) explicitly include LCA and carbon footprinting contents in their syllabus. These five schools normally offered these modules as an optional alternative, with only three of them $(12 \%)$ offering sustainability and/or environmental engineering modules as core subjects, and exclusively one (4\%) including LCA and carbon footprint in the mandatory modules.

Therefore, a contradiction is apparent between the importance of sustainability (and LCA/carbon footprinting) in research areas and in the expected role of a chemical engineer, versus the transference of this knowledge via the syllabus. This is in line with results obtained by Byrne et al. (2013), who remarked that although there is a consensus about the importance of integrating sustainability and sustainable development into engineering curricula, little 
progress has been seen regarding an effective integration of these concepts (Allen et al., 2009). In turn, this delays the development of sustainable engineering skills (Desha et al., 2009).

Professional engineering institutions have helped to glimpse the future demands of professionals as they play an active role in anticipating and responding to society's future needs (IChemE, 2013). For example, the Institution of Chemical Engineers (IChemE), with a presence in 17 countries, includes among the mission of chemical engineers to address the "range of processes, technologies and strategies that will help achieve more sustainable living in the $21^{\text {st }}$ Century" (IChemE, 2013) and has developed a sustainability special interest group with the aim "to make sustainable development a core concept in the teaching and practice of chemical engineering" (IChemE, 2017). Thus, it is highly appropriate to develop teaching approaches that introduce sustainability and, more specifically, life cycle thinking concepts in chemical engineering modules.

\section{Literature review of teaching LCA in chemical engineering}

Across the literature, there are several examples of good LCA teaching practices applied in engineering curricula. Using key words such as 'LCA education', 'teaching LCA', 'LCA pedagogy', 'teaching life cycle assessment', and similar, in research engines including Scopus, ScienceDirect and Google Scholar, several articles were found. Then, they were selected based on one criterion: application into chemical engineering curricula. Exceptions were made when innovative or cross engineering examples were found (see Table 1). When teaching-focused literature is reviewed, most of the publications in sustainability, particularly on teaching LCA, describe the approach taken by the authors through a detailed explanation of case studies and the resources used, such as specific software and databases (Mälkki and Alanne, 2017; Gilmore 2016; Riley 2015), or the analysis of students' feedback related to the 
concepts learnt, the learning outcomes reached and the effectiveness of the teaching approaches and methods used (Mulder, 2017; Weber et al.,2014).

Prior relevant literature is summarised in Table 1. As shown in the table, similar characteristics are seen when specific chemical engineering focused samples are assessed; the publications concentrate on the description of the course and activities (coursework) as a way to show the incorporation of LCA and carbon footprint in the curricula. For instance, Crossin et al. (2011) described how a course was developed and what the target audience was. The authors gave an overview of the whole course, the resources used and the teaching techniques, which mainly focused on learning the LCA framework and being able to develop its documentation. The course used commercial LCA software (SimaPro) and a variety of learning approaches including lectures, weekly short tutorials and 'minor and major' projects with a broad scope. The course was compulsory within the host department but also offered as an elective across the whole university. The provision of consolidated LCA teaching across multiple subject areas is also reported by Evans et al. (2008), who used problem solving and group discussions to teach LCA to first year engineering and science students. In this case LCA was included as part of an overarching theme of optimisation which was relevant to all cohorts.

The use of prior publications as a resource is highlighted by Belboom and Léonard (2016), who gave their students published LCA papers as tools to promote learning, understanding and practicalities related to LCA, and at the same time, to promote the development of reviewing skills. Similarly, Meo et al. (2014) also used published LCA papers, specifically those with detailed available inventories, for learning and practising the use of the LCA software, and for developing the case studies of the course. In this case, the authors explained the software selection criteria (e.g. affordable, easy to use, online remote access, etc.), which is a cloud-based commercial software (Sustainable Minds ${ }^{\mathcal{O}}$ ), and how they implemented it in 
the course. In terms of the teaching approach, Table 1 shows that almost all examples are based on problem- or project-based learning with students working on case studies either in groups or individually. However, novel approaches like a game-based learning initiative or ‘role play' are presented by Bevilacqua et al. (2015) and Fletcher et al. (2008), respectively.

The literature also shows that LCA teaching is not only taught as a stand-alone course. For instance, Riley (2015) included concepts such as climate change and LCA as well as socioeconomic aspects like ethics and economic inequality in modules on Engineering Thermodynamics and Mass and Energy Balances. The author describes that, in the case of the thermodynamics course, one of the main ideas behind her approach is to help students to think critically and to connect concepts, in this case the thermodynamic principles, with daily life problems and engineering ethics. Similarly, Othman et al. (2012) dedicated one day of a 20 day module on Computer Aided Plant Design (CAPD) to teach sustainability, focusing on enhancing process design and selection criteria using LCA and multi-criteria decision tools.

Another approach is to integrate LCA into the 'Freshman Clinic' courses (laboratories) across the whole chemical engineering curriculum at Rowan University (Savelski et al. (2013); Farrell and Cavanagh (2014)). In these cases, the students learn and design biodiesel processes in an experimental setting, but also assess their environmental impacts and compare their results with fossil fuels. In this practice, the learning outcomes are not only focussed on technical skills (e.g. LCA framework, development of inventory data from laboratory experience, learning LCA software) but also on non-technical ones, like communication skills (oral and writing) as well as teamwork. Moreover, Savelski et al. (2013) explained that the students' interaction with industrial partners during the course, specifically through project presentations, increase the development of non-technical skills related to employability, communication and real life experience. 
Such non-technical skills have also been imparted alongside knowledge of LCA by combining teaching with public engagement activity. For instance, Taboada et al. (2011) moved the LCA teaching outside the classroom, engaging engineering students with high school teachers and pupils as a way to promote sustainability and the environmental engineering career.

Finally, some studies remark that another important characteristic that helps with the implementation of LCA in the curriculum is the presence of research groups working on the field and using the tool. This is the case of Belboom and Léonard (2016) and Cross et al. (2011), who mentioned the relevance of the research group to the development of the course across the school and university.

These examples and others have improved substantially the implementation of LCA teaching in STEM disciplines. However, the search remains open for new approaches that are easy to apply in chemical engineering, with zero or minimal costs, worldwide validity and sufficient flexibility to cover such holistic topics. 
Table 1: Literature review on life cycle assessment teaching in the chemical engineering (ChemEng) curricula

\begin{tabular}{|c|c|c|c|c|c|}
\hline Article & Content & Teaching approach & Learning outcomes ${ }^{a}$ & Programme $^{b}$ & Engineering subject \\
\hline $\begin{array}{l}\text { Belboom } \\
\text { and Léonard, } \\
2016\end{array}$ & Description of course and coursework & $\begin{array}{l}\text { - Theory (lectures), guided discussion and analysis, } \\
\text { discussion and assessment of LCA papers individually } \\
\text { and in groups from technical and quality perspectives }\end{array}$ & $\mathrm{T} / \mathrm{N}$ & $P$ & - ChemEng \\
\hline $\begin{array}{l}\text { Gilmore } \\
2016\end{array}$ & $\begin{array}{l}\text { LCA teaching integration in the engineering } \\
\text { curriculum for different knowledge levels }\end{array}$ & - Theory (lectures) and problem based learning & $\mathrm{T}$ & $\mathrm{U} / \mathrm{P}$ & $\begin{array}{l}\text { - ChemEng, Civil } \\
\text { Environmental, Mechanical }\end{array}$ \\
\hline $\begin{array}{l}\text { Bevilacqua } \\
\text { et al. } 2015\end{array}$ & $\begin{array}{l}\text { Description of the course and coursework and } \\
\text { thorough analysis of feedback }\end{array}$ & $\begin{array}{l}\text { - Game learning, role play, group discussion and } \\
\text { computer/software learning }\end{array}$ & $\mathrm{T} / \mathrm{N}$ & $\mathrm{U}$ & -Engineering \\
\hline Riley, 2015 & $\begin{array}{l}\text { Description of the course and the activities } \\
\text { and critical assessment of the initiative }\end{array}$ & $\begin{array}{l}\text { - Problem-based learning, group discussion and } \\
\text { reflective essays }\end{array}$ & $\mathrm{T} / \mathrm{N}$ & $\mathrm{U}$ & - Engineering \\
\hline $\begin{array}{l}\text { Farrell and } \\
\text { Cavanagh, } \\
2014\end{array}$ & Description of the course and the coursework & $\begin{array}{l}\text { - Theory, group discussion, hands on, problem-based } \\
\text { learning, project-based learning and computer } \\
\text { laboratories }\end{array}$ & $\mathrm{T} / \mathrm{N}$ & $\mathrm{U}$ & - Engineering \\
\hline $\begin{array}{l}\text { Savelski et } \\
\text { al. } 2013\end{array}$ & Description of the activities & - Hands-on ${ }^{\mathrm{c},}$ minds-on ${ }^{\mathrm{c}}$ and project based learning & $\mathrm{T} / \mathrm{N}$ & B & $\begin{array}{l}\text { - ChemEng and all } \\
\text { engineering programs }\end{array}$ \\
\hline $\begin{array}{l}\text { Othman et } \\
\text { al. } 2012\end{array}$ & $\begin{array}{l}\text { Description of the course coursework and } \\
\text { students feedback }\end{array}$ & - Theory (lectures) and problem based learning & $\mathrm{T}$ & $P$ & - ChemEng \\
\hline $\begin{array}{l}\text { Crossin et } \\
\text { al. } 2011\end{array}$ & $\begin{array}{l}\text { Description of the course, activities and } \\
\text { feedback }\end{array}$ & $\begin{array}{l}\text { - Theory (lectures), group activities, computer-based } \\
\text { tutorials, problem based learning and field trip }\end{array}$ & $\mathrm{T}$ & $\mathrm{U}$ & $\begin{array}{l}\text { - ChemEng, Civil, } \\
\text { Environmental, Mechanical }\end{array}$ \\
\hline $\begin{array}{l}\text { Taboada et } \\
\text { al. } 2011\end{array}$ & Description of the course and activities & $\begin{array}{l}\text { - Theory, project-based learning and group discussion } \\
\text { - Learning by teaching (outreach activities) }\end{array}$ & $\mathrm{T} / \mathrm{N}$ & $\mathrm{U}$ & - Engineering \\
\hline $\begin{array}{l}\text { Evans et al. } \\
2008\end{array}$ & $\begin{array}{l}\text { Description of the case studies, resources use } \\
\text { and student feedback }\end{array}$ & - Problem based learning and group discussion & $\mathrm{T} / \mathrm{N}$ & $\mathrm{U}$ & - ChemEng \\
\hline $\begin{array}{l}\text { Fletcher et } \\
\text { al. } 2008\end{array}$ & $\begin{array}{l}\text { Description of the courses, focussing on the } \\
\text { role play approach }\end{array}$ & $\begin{array}{l}\text { - Role play, theory (lectures), project based learning, } \\
\text { computer based tutorial (software), hands on activities }\end{array}$ & $\mathrm{T} / \mathrm{N}$ & $\mathrm{U}$ & $\begin{array}{l}\text { - ChemEng, Mechanical } \\
\text { engineering and design. }\end{array}$ \\
\hline
\end{tabular}

${ }^{a}$ Sourced from Nasir et al. (2011) where T means technical skills and $\mathrm{N}$ means non-technical skills focus

${ }^{\mathrm{b}}$ Programme refers to the educational level, meaning postgraduate $(\mathrm{P})$, undergraduate $(\mathrm{U})$ or Bachelor $(\mathrm{B})$

${ }^{c}$ As described by the authors (Savelski et al. 2013). 


\section{Coursework case study}

\subsection{Introduction}

The present case study has been applied over two years within the School of Chemical Engineering and Analytical Science of The University of Manchester (UK), one of the top 25 chemical engineering schools worldwide. It has been implemented as part of the module 'Sustainable Development \& Industry' in the programmes Master of Engineering (MEng) Chemical Engineering, MEng Petroleum Engineering and Master of Science (MSc) Advanced Chemical Engineering.

\subsection{Theoretical lecture}

The theoretical part of this coursework includes an initial three hour lecture about carbon footprint and LCA, combining theory, industrial experience and an introduction to software. In the first hour, basic LCA concepts are explained in detail, including life cycle thinking and the structure of the ISO standard framework, which contains the definition of the goal and scope, system boundaries, functional unit, inventory analysis, estimation of impacts (including carbon footprint) and interpretation of results. The benefits and difficulties of the implementation of LCA are presented as well as some examples of its applications. This is extended during the second hour via a guest lecturer who explains their own experience of implementing LCA in an industrial sector; speakers from the food and construction sectors have participated in the last two years. If inviting an industrial speaker was impractical, any of the examples available in the literature could be used instead (see, for instance, Azapagic and Perdan, 2011). This part of the lecture provides an opportunity to discuss commercial benefits of LCA such as environmental product declarations or certification.

Finally, in the third hour, an overview of the freely available software CCaLC (Carbon Calculations over the Life Cycle of Industrial Activities) is introduced. Here the students 
learn how to start modelling and define different life cycle stages as well as to calculate impacts and identify hotspots. This is complemented by a step-by-step user guide available in the university's online learning environment. A comprehensive user guide is also available in the CCaLC webpage (http://www.ccalc.org.uk/ccalc2.php). This LCA software has been chosen because it is free of charge, designed for industrial users (i.e. non-experts in LCA), is based on the ISO Standards, uses robust and well known databases (e.g. Ecoinvent), and allows not only the estimation of carbon footprint but also other environmental impacts like acidification and eutrophication, water footprint and economic measures (CCaLC, 2017).

\subsection{CCaLC coursework}

The students are divided into groups of 8-10 and assigned a tutor before undertaking a coursework activity that spans three days for three hours per day. The main aims of the coursework are to:

- learn how to apply life cycle thinking and to become familiar with LCA;

- learn how to calculate life cycle environmental impacts, in particular carbon footprint, by using LCA software (CCaLC);

- gain understanding of the usefulness and drawbacks of LCA as a tool;

- use LCA alongside non-environmental criteria to make decisions; and

- practise and develop employability-related skills including critical analysis, oral presentation and conflict resolution.

The contents of Days 1-3 are detailed in the following sections.

\subsubsection{Day 1: Baseline environmental assessment}

Students complete two activities during the first day: individual estimation of the carbon footprint of the production of a plastic water bottle with CCaLC, followed by preparation of a 
short group presentation (15 minutes maximum) including the results, ideas for possible improvements, and potential problems associated with those improvements.

The first activity familiarises the students with the software and provides a first-hand practical application of the theoretical concepts learned via a real industrial process. The presentation activity is outlined during Day 1 , and the group should collaboratively develop their presentation before Day 2.

\subsubsection{Day 2: Scenarios - environmental, economic and social impacts}

First, students deliver the presentation prepared at the end of Day 1. Evaluation of the presentation is based upon accuracy of the results, novelty and feasibility of the ideas, evidence of understanding of the environmental, economic and social aspects of sustainable development, timekeeping and fair participation by all group members.

Afterwards, each group is divided into two teams (A and B) with four or five students each. Each team models the carbon footprint of two alternatives to improve the sustainability of the current production process of the water bottle. Team A must model a light-weighting scenario and a bio-based materials scenario, while team B considers increased use of recycled material and the installation of a cogeneration plant at the production facility. Each of the alternatives has some advantages and disadvantages from the sustainability point of view. For example, in the case of the use of bio-based materials, the students should consider that this decision could seriously compromise the viability of a local supplier of Polyethylene terephthalate (PET) resin because the water bottling company is their best customer. There is a possibility of job losses in the local community and $75 \%$ of the end product is sold in a radius of 50 miles. Other points to consider are that ecologists will start a campaign against this solution on the basis that arable lands should be used to produce products for feeding people, not to 
produce bio-plastics and that an initial investment of $£ 250,000$ is necessary to adapt the production process.

By Day 3, each team must prepare another 15 minute presentation with the results of both scenarios, including a justified choice of one favoured option and ideas to mitigate any drawbacks of the chosen scenario.

\subsubsection{Day 3: Sustainability assessment and discussion}

Each team delivers their presentation to justify their decision-making. Evaluation considers aspects like obtaining the correct results, justification of the final decision, evidence of creativity and understanding to mitigate drawbacks, fair participation by all group members and timekeeping.

Once the presentations are finished, teams A and B debate together the four scenarios and the suggested ways to mitigate drawbacks. By the end, everyone should agree on one solution which may incorporate parts of different scenarios, where possible. It must include a feasible environmental improvement as well as consideration of the economic and social aspects. This is the only section of the coursework in which each student is marked individually based on their engagement in the discussion, demonstration of depth of understanding and ability to make convincing arguments and negotiate with other members.

\subsection{Student feedback}

Student feedback was acquired at the end of the module during the 2015/2016 and 2016/17 academic years. The students were asked to complete an online survey in which they must agree or disagree with a set of statements via a scale of 1-5 corresponding to 'disagree', 'mostly disagree', 'neither agree or disagree', 'mostly agree' and 'agree'. Questions probed their perception of the coursework, the unit overall, aspects that were valued and aspects that could be improved. The weighted mean was calculated for each question, resulting in a score 
from one to five, with five being the most desirable outcome. The survey completion rate was $59 \%$ (59 students out of 100) in 2015/2016 and 43\% (43 students out of 99) in 2016/2017.

\section{Results and discussion}

The outcomes of the coursework implementation described above are discussed in the following sections with reference to student feedback and with consideration of pedagogical, employability and practical aspects.

\subsection{Benefits of the present approach}

Overall student feedback on the coursework was positive. The statement 'the coursework set was a useful aid to learning' resulted in a mean score of $4.41 / 5$, or $88 \%$ agreement, in $2015 / 16$ and $4.44 / 5(89 \%)$ in $2016 / 2017$. Based on prior experience of survey feedback, this is a high score. The feedback of both years provide some suggestion that the initial aim of the coursework framework was achieved; namely, to provide a well-balanced combination of practical and theoretical concepts in an interactive approach that makes complex concepts such as LCA or carbon footprint more interesting for the chemical engineer student.

The presentation of real case studies applying LCA and carbon footprint frameworks motivates students to learn these environmental tools by demonstrating their applicability and the potential to increase the students' future employability. Since enhancement of employability was one of the goals in this teaching activity, it is useful to first consider what 'employability' refers to. At a high level, this can be characterised simply by the overarching need to gain and retain employment in a moving market (Hillage and Pollard, 1998), but this can be more practically expressed in terms of skills and attributes of different types. For instance, McQuaid and Lindsay (2005) describe a hierarchical set of skills progressing from 'basic transferable skills' (such as numeracy and verbal presentation) to 'key transferable skills' (including problem-solving and team working) through to 'high level transferable 
skills' (including appreciation of continuous learning and commercial awareness). Thus, in line with the principle of key transferable skills, the current case study framework goes beyond the correct calculation of results, prompting the students to understand and anticipate in sustainability problems, communicate their findings and negotiate/discuss in groups through a real life problem with a problem-solving approach. Other skills developed are software learning and practical application, development of critical thinking, presentation and argumentation skills, experience in solving conflicts and getting to agreements. Consequently, as shown in Table 2, there is a clear overlap with the competences required by the Engineering Council to gain accreditation under its UK Standard for Professional Engineering Competence (EC UK, 2014).

Table 2: Mapping of coursework onto Engineering Council UK-SPEC (EC UK, 2014)

\begin{tabular}{|l|l|}
\hline \multicolumn{1}{|c|}{ Competence area } & \multicolumn{1}{|c|}{ Mapping onto coursework } \\
\hline $\begin{array}{l}\text { Maintain and extend a sound theoretical approach to } \\
\text { the application of technology in engineering } \\
\text { practice. }\end{array}$ & $\begin{array}{l}\text { The LCA and carbon footprinting theoretical concepts are } \\
\text { introduced and applied to engineering practice. }\end{array}$ \\
\hline $\begin{array}{l}\text { Use a sound evidence-based approach to problem- } \\
\text { solving and contribute to continuous improvement. }\end{array}$ & $\begin{array}{l}\text { Students must identify the environmental hotspots of the case study } \\
\text { and propose technical solutions. }\end{array}$ \\
\hline $\begin{array}{l}\text { Contribute to the design and development of } \\
\text { engineering solutions, their implementation and } \\
\text { evaluation. }\end{array}$ & $\begin{array}{l}\text { Students must propose and design solutions and evaluate and } \\
\text { discuss the implementation with other students in the final debate. }\end{array}$ \\
\hline $\begin{array}{l}\text { Plan for effective implementation and manage } \\
\text { teams and tasks. }\end{array}$ & $\begin{array}{l}\text { Students must work effectively in relatively large teams with } \\
\text { limited time to complete the task. }\end{array}$ \\
\hline $\begin{array}{l}\text { Communicate in English with others at all levels, } \\
\text { present and discuss proposals and demonstrate } \\
\text { personal and social skills. }\end{array}$ & $\begin{array}{l}\text { Oral abilities are developed through the two presentations and the } \\
\text { final debate. Social and personal skills are developed through the } \\
\text { preparation of the presentations (e.g. flexibility to work with } \\
\text { previously unknown colleagues, ability to resolve conflicts or } \\
\text { encourage work towards collective goals) and are necessary again } \\
\text { to recognise the concerns of others and find agreement in the final } \\
\text { debate. }\end{array}$ \\
\hline $\begin{array}{l}\text { Undertake engineering activities in a way that } \\
\text { contributes to sustainable development. }\end{array}$ & This is the focus of the case study material. \\
\hline
\end{tabular}


In answering the prompt, 'please provide details of what you valued about this unit' student comments included, 'the coursework set was completely different... it was useful in practising presentation and debating skills which you don't really get the opportunity to do in most units'. This suggests that particularly valued the chance to practise communication skills. Appreciation was also demonstrated for the key transferable skills brought about via the applied, problem-oriented, team-based nature of the coursework ('The coursework was a helpful way to understand the LCA by applying [it] to an industrial case'; '[I valued] the engaged learning from doing group exercises - I learnt from other people's perspective rather than just a book's perspective').

In reference to the high level transferable skills mentioned earlier (McQuaid and Lindsay, 2005), business thinking and commercial awareness are also practised in this activity as the students are required to consider the economic consequences of their own production scenarios as well as social and ethical implications, balancing the need to produce profit while maintaining reputation and operating effectively with the surrounding community.

Chemical engineering covers a wide spectrum of disciplines and specializations and therefore, successful teaching approaches have to be flexible enough to be applied in different academic fields, and learning outcomes should be applicable in different professional activities. Data from The University of Manchester shows that, between 2013 and 2016, chemical engineering graduates found employment across 59 Standard Occupational Classification codes spanning 190 employers in sectors as diverse as energy, food, high-tech manufacturing, finance and pharmaceuticals, to name only a few. In this heterogeneous environment, the fact that $\mathrm{CCaLC}$ includes more than 6000 data items from robust, reliable sources covering many sectors gives this coursework structure enough flexibility to be adapted for different sectors. For example, if the course is focused on transport, the coursework can be adapted with minimum changes to investigate and compare the sustainability of traditional and bio-fuels. 
This flexibility goes even beyond the implementation of the coursework in chemical engineering curricula, allowing the application into any engineering career. This is demonstrated by the fact that this coursework is attended by students from the MEng Petroleum Engineering.

In addition to broad sectoral relevance, this framework also encourages transdisciplinary thinking, which has previously been identified as an employability benefit. As highlighted by the Institute for the Future (IFTF, 2011), transdisciplinary is one of the ten skills that will drive future jobs by 2020. IFTF remarks that as worldwide problems become increasingly complex non-specific disciplines will be the key to solve them as they will require multidisciplinary approaches and transdisciplinary professionals. Similarly, the NAE (2004) identify aspirations to tackle multidisciplinary challenges with creativity and open mindedness. Moreover, team-work and critical thinking activities conducted within the highly international environment of MEng and MSc programmes are also aligned with another two of the ten skills defined by IFTF: 'cross cultural competency' and 'novel and adaptive thinking'.

In addition to the transferable skills discussed above, the specific content of the coursework is highly relevant to certain fields of consultancy that have seen increasing demand in recent years. Namely, the production of Environmental Product Declarations (EPDs) is increasingly desirable in industry: in the last 5 years 2,500 EPDs have been published worldwide and 300 in the UK (Environdec, 2017: IBU, 2017). From this employability perspective, CCaLC has been downloaded more than 6000 times and used successfully in the industry (e.g. Kellogg or Ineos ChlorVinyls) or as a research tool (e.g.: Iriarte et al. (2014), Jeswani et al. (2013)). In the case of research and higher education, LCA has become a major focus of interest with more than 25,000 journal contributions (more than 2,000 in the UK) only in the last ten years (Scopus, 2017). This demonstrates the future impact of the knowledge learned by the 
students, both for industrial and research purposes. Finally, teaching programmes using this concept should be affordable and easy to manage, allowing widespread adoption worldwide, including in developing countries. CCaLC is a free piece of software and, therefore, can be downloaded anywhere with internet access at no cost. This characteristic differentiates this practical coursework from others normally applied in chemical engineering (e.g. laboratories or licenced commercial software), which often have high cost.

\subsection{Drawbacks of the present approach}

The previous section highlighted the acquisition of many forms of transferable skills. However, while such diverse skills can improve students' chances of employment, there is a danger that representing employability as a list of skills is an oversimplification that is not reflective of the complex set of characteristics valued by employers (Knight and Yorke, 2006; Yorke, 2006). One potential remedy is to acknowledge that teaching does not simply provide skills, but also encourages attitudes that recognise the life-long nature of the process and empower students to learn continuously in a critical, reflective manner (Harvey, 2000). Therefore, increasing the employability of students requires exposing them to activities that develop personal qualities and attitudes in addition to 'skills'. These qualities might also be interpreted as the ' $\mathrm{E}$ ' and ' $\mathrm{M}$ ' components in Yorke and Knight's USEM model (understanding, skills, efficacy beliefs, metacognition) (Yorke and Knight, 2006). In order to encourage metacognition and 'learning how to learn', the use of skills in different settings must be repeated and accompanied by useful feedback, which proves a challenge with large class sizes.

In this case the provision of robust, clear marking and detailed feedback remains the main point for improvement and was the only area of negative feedback in an otherwise positive student surveys. In response to the prompt, 'please provide details of what you think could be improved on this unit', replies included 'the coursework marks are something that didn't 
seem too consistent as they were judged for different groups by different demonstrators' and 'the method of marking the coursework is not standardised. Marks from every group vary.'

In both academic years in which the coursework has run (2015/16 and 2016/17), the marks were normalised ex post in an attempt to control inter-group variation. During year 2016/2017, the marking scheme was improved with a more explicit rubric. Results from these two years suggest that the above actions may have reduced some of the unwanted variation in marking: from 2015/16 to 2016/17 the standard deviation of unmoderated mean marks for each group decreased from $6 \%$ to $5.5 \%$, while the standard deviation of marks across the entire taught group decreased from $9.7 \%$ to $6.4 \%$. While it is not desirable to remove variation in marking to the extent that it compromises the discriminatory power of the coursework, this does suggest that tutors have made attempts to standardise their marking. During the next year, further attempts to reduce this variance will include a more detailed briefing for tutors, explaining in detail the evaluation process with examples, and a meeting after the first evaluation (Day 2), to discuss the tutors' experiences, compare the results, and explain and discuss their first marking, as a way to normalise approaches and avoid such marking variations.

The coursework is designed for small groups of 8-10 people led by a tutor. A maximum of 15 students per tutor can be considered but a greater increase would limit personal engagement and hinder attempts to evaluate the individual progress of each student. If the global number of students is high, this also necessitates a considerable number of computers, desks and tutors. In both years of implementation, the coursework was delivered to $80-100$ undergraduate and postgraduate students per year, employing an average of $10 \mathrm{PhD}$ students and postdoctoral fellows as tutors. The number of tutors may imply an extra cost as well as the variability in marking described above as a result of the demonstrators' value judgments potentially influencing the marking of three presentations and debates. 
The implementation of this teaching unit implies the use of 12 face-to-face hours of class. This amount of time could be seen as excessive if only a basic notion of LCA is required. In this sense, the didactic unit can be adapted to consist of an hour and a half theoretical session with basic concepts of LCA and an overview of CCaLC, and another hour and a half centred on the calculation of a practical case with the software. This approach implies losing several of the educational benefits (e.g. communication, teamwork and discussion skills or deeper understanding of life cycle thinking or sustainability problems) but shows the flexibility of the proposal to be adapted for time-constrained courses.

The organization of this unit is time demanding, especially if the number of students is high or the practical content of the course must be adapted to a specific case or topic. In our experience, the preparation of the theoretical lecture took around five hours, including inviting guest lecturers. Selection and training of the 10 tutors and reservation of teaching spaces took another five hours. If the framework requires adaption to another field or topic, this will affect mainly Days 1 and 2 (see sections 4.3.1 and 4.3.2). A new base case and four more scenarios would be required, with a time investment of approximately 5-10 hours. This total demand of time (15-20 hours) for a group of 80-100 students will naturally reduce after the first year due to repeated use of the same content, tutors and/or guest lecturers.

Finally, aside from practical difficulties in delivering skills, it is also important that academics communicate to their students the skills that they are developing during the activity and highlight the terminology used by employers to describe those skills. If students are not aware of the skills they are practising, they will have difficulty communicating those skills to prospective employers; in other words it is important to 'make the tacit explicit' (Pegg et al., 2012). Although the current marking scheme explicitly evaluates some of the key transferable skills (e.g. presentation and argumentation skills and team work), other skills are implicit in the coursework but not directly evaluated (e.g. software learning and development of critical 
thinking). Hence, future improvements will seek to address the expected learning outcomes of the module in a more explicit manner, to discuss and highlight aspects such as the employability related skills that this coursework provides and its relevance to industrial or consultancy work experience. These aspects would be corrected in future years by describing the acquired skills and how they will be evaluated in outlines and introductions of both the coursework and the unit as a whole. Finally, changing in the scoring systems will be made to measure each key transferable skill, to then analyse the progression along the difference cohorts.

\section{Conclusions}

Most of the top 25 chemical engineering schools (64\%-88\%) have research areas directly related with sustainability and/or environmental engineering, offer modules related with these topics or reference them when mentioning the mission of the school and/or when defining the future role of a chemical engineer. In the case of LCA and carbon footprint, $40 \%$ of the schools conduct research involving these topics. However this interest is not reflected in the introduction of LCA and carbon footprint in the syllabus as only $20 \%$ of schools include them in their modules, with just one school (4\%) having a mandatory course.

A literature review has shown that, despite evidence of good LCA teaching practice in engineering curricula, there remains a lack of approaches that are easy to apply, free of cost, valid worldwide and sufficiently flexible to cover such a holistic topic. As a possible solution, this study presents the implementation and results, over two academic years, of an LCAbased coursework in the School of Chemical Engineering and Analytical Science of The University of Manchester, one of the top 25 schools worldwide. The coursework framework is based on free software containing data on more than 6000 processes, making it affordable and flexible enough to be implemented in different engineering curricula in diverse cultural backgrounds worldwide. 
The coursework combines lectures, group work, software modelling, problem solving, presentation and structured debate, in order to go beyond simply imparting knowledge, by improving the employability of students. It achieves the latter by fostering basic, key and high-level transferable skills including problem solving and problem anticipation, teamwork, communication, conflict resolution, critical thinking, decision making, broad commercial awareness and ethical cognizance.

The student feedback reflects the development of these skills as one of the major advantages highlighted of this coursework, both via specific comments from students and the $89 \%$ agreement with the survey phrase, 'the coursework set was a useful aid to learning'. The improvement area was the consistency of marking. For the second year, the feedback and marking scheme was improved with a more explicit rubric and the standard deviation of unmoderated mean marks across the entire taught group decreased from $9.7 \%$ to $6.4 \%$. This and other detected drawbacks, like the amount of face-to-face hours of teaching and the amount of time needed to organise this coursework, are not unusual challenges for coursework and can be overcome. A final area identified for future enhancement is the realisation by students of the skills they are developing. This will be improved by an explicit outline in the syllabus and coursework description.

\section{References}

Allen, D., Allenby, B., Bridges, M., Crittenden, J., Davidson, C., Hendrickson, C., Matthews, S., Murphy, C. and Pijawka, D. (2009). "Benchmarking Sustainable Engineering Education: Final Report", working paper, Center for Sustainable Engineering, Syracuse, New York, $21^{\text {st }}$ February.

Azapagic, A and Perdan, S. (2011), Sustainable Development in Practice: Case Studies for Engineers and Scientists, Wiley-Blackwell, West Sussex, UK. 
Belboom, S. and Léonard, A. (2016), “Teaching of Life Cycle Assessment methodology to sensitize future engineers to sustainable development", paper presented at $8^{\text {th }}$ Conference on Engineering Education for Sustainable Development. 4-7 September, Bruges, Belgium, available at: https://orbi.ulg.ac.be/bitstream/2268/202511/2/ Belboom_S_et\%20al_EESD_2016_engineer_LCA.pdf (accessed 20 September 2017).

Bevilacqua, M., Ciarapica, F.E., Mazzuto, G. and Paciarotti, C. (2015), “““Cook \& Teach”: learning by playing”, Journal of Cleaner Production, Vol. 106, pp. 259-27.

Bird, J. and Lawton, K. (2009), “The Future's Green: Jobs and the UK low carbon transition”, working paper, Institute for Public Policy Research. London, UK, October.

Bowen, A. and Kuralbayeva, K. (2015), “Looking for green jobs: the impact of green growth on employment", working paper, The Grantham Research Institute on Climate Change and the Environment and Global Green Growth Institute (GGGI), London, UK, March.

BSI EN 15804 (2012), "Sustainability of construction works - Environmental product declarations - Core rules for the product category of construction products", standard, British Standards Institution (BSI), London, UK.

BSI PAS 2050 (2011), "Specification for the assessment of the life cycle greenhouse gas emissions of goods and services", standard, British Standards Institution (BSI), London, UK.

Byrne, E. P., Desha, C.J., Fitzpatrick, J.J. and Hargroves, K.C. (2013), "Exploring sustainability themes in engineering accreditation and curricula", International Journal of Sustainability in Higher Education, Vol. 14 No. 4, pp.384-403.

CCaLC (2017), “Carbon Calculations over Life Cycle of Industrial Activities”, available at: http://www. ccalc.org.uk/ (accessed 20 September 2017) 
Crossin, E., Carre, A., Grant, T., Sivaraman, D. and Jollands, M. (2011), "Teaching Life Cycle Assessment; greening undergraduate engineering students at RMIT University", paper presented at $7^{\text {th }}$ Australian Conference on Life Cycle Assessment, 9 -10 March, Melbourne (Australia), available at: https://s3.amazonaws.com/academia.edu. documents/6646054/crossin_alcas_paper.pdf?AWSAccessKeyId=AKIAIWOWYYG Z2Y53UL3A\&Expires=1502460663\&Signature=z8Ozqxcqu5qA2rmQ\%2BjsHGL1xS bk\%3D\&response-contentdisposition=inline\%3B\%20filename\%3DTeaching_Life_Cy cle_Assessment_greening.pdf (accessed 20 September 2017).

Desha, C.J., Hargroves, K. and Smith, M.H. (2009), “Addressing the time lag dilemma in curriculum renewal towards engineering education for sustainable development". International Journal of Sustainability in Higher Education, Vol. 10 No. 2, pp. 184199.

EC UK (2014), "UK-SPEC, the UK Standard for Professional Engineering Competence", working paper, Engineering Council, London, UK, January.

Emas, R. (2015), "The concept of sustainable development: definition and defining principles”, Florida International University, Miami (USA).

Environdec (2017)," EPD database", available at: http://environdec.com/Epd-Search/? search_type $=$ simple $\&$ Category $=6192$ (accessed: 20 September 2017)

Evans, G.M., Galvin, K.P., and Doroodchi, E. (2008). "Introducing quantitative life cycle analysis into the chemical engineering curriculum", Education for Chemical Engineers, Vol. 3, No. 1, pp 57- 65.

Farrell, S., and Cavanagh, E. (2014), “An introduction to life cycle assessment with hands-on experiments for biodiesel production and use", Education for Chemical Engineers, Vol. 9 No. 3, pp. 67-76. 
Fletcher, J.P., Drahun, J.A., Davies, P.A. and Knowles, P. (2008), "The Teaching of Sustainable Development at Aston University" working paper, The Higher Education Academy Engineering Subject Centre and the UK Centre for Materials Education, York (UK).

Gilmore, K.R. (2016), “Teaching life cycle assessment in environmental engineering: a disinfection case study for students", The International Journal of Life Cycle Assessment, Vol. 21 No. 12, pp. 1706-1718.

Hall, G.M. and Howe, J. (2010), "Sustainability of the chemical manufacturing industry Towards a new paradigm?", Education for Chemical Engineers, Vol. 5 No. 4, pp. 100107.

Harvey, L. (2000), "New realities: the relationship between higher education and employment", Tertiary Education and Management, Vol. 6, pp. 3-17.

Hillage, J. and Pollard, E. (1998), "Employability: developing a framework for policy analysis" working paper, Department for Education and Employability, London (UK).

HM Government (2009), "Low Carbon Industrial Strategy: A vision”, working paper, Department for Business, Enterprise and Regulatory Reform and Department of Energy and Climate Change, London, UK, March.

IBU (2017), "Published EPDs", available at: https://epd-online.com/PublishedEpd (accessed 20 September 2017).

IChemE (2013), “Chemical Engineering matters”, working paper, The Institution of Chemical Engineers, Rugby (UK).

IChemE (2017), "Sustainability Special Interest Group”, available at: http://www.icheme. org/communities/special-interest-groups/sustainability/about_us.aspx (accessed 20 September 2017). 
IFTF (2011), "Future Work skills 2010", working paper, Institute for the Future for the University of Phoenix Research Institute, Phoenix (USA).

Iriarte, A., Almeida, M.G. and Villalobos, P. (2014), "Carbon footprint of premium quality export bananas: Case study in Ecuador, the world's largest exporter", Science of the Total Environment, Vol. 472, pp. 1082-1088.

ISO 14025 (2006), "Environmental labels and declarations - Type III environmental declarations - Principles and procedures", standard, International Standard Organization (ISO), Geneva, (Switzerland).

ISO 14040 (2006), “Environmental management - Life cycle assessment - Principles and framework", standard, International Standard Organization (ISO), Geneva, (Switzerland).

ISO 14067 (2013), “Greenhouse gases - Carbon footprint of products - Requirements and guidelines for quantification and communication", standard, International Standard Organization (ISO), Geneva (Switzerland).

Jeswani, H.K., Smith, R.W. and Azapagic, A., (2013). "Energy from waste: Carbon footprint of incineration and landfill biogas in the UK", International Journal of Life Cycle Assessment, 18 (1), pp. 218-229.

Knight, P. T. and Yorke, M. (2006), “Employability: judging and communicating achievements", in Learning \& Employability Series 1, The Higher Education Academy, York (UK).

Mälkki, H. and Alanne, K. (2017), "An overview of life cycle assessment (LCA) and research-based teaching in renewable and sustainable energy education", Renewable and Sustainable Energy Reviews, Vol.69, pp. 218-231. 
McQuaid, R. and Lindsay, C. (2005), “The concept of employability”, Urban Studies, Vol. 42, pp. $197-219$.

Meo, M., Bowman, K., Brandt, K., Dillner, M., Finley, D., Henry, J., Sedlacek, K. and Winner, A. (2014), “Teaching Life-Cycle Assessment with Sustainable Minds ${ }^{(}$- A Discussion with Examples of Student Projects", Journal of Sustainability Education, Vol. 7, pp. 2151-7452.

Mulder, K.F. (2017), “Strategic competences for concrete action towards sustainability: An oxymoron? Engineering education for a sustainable future", Renewable and Sustainable Energy Reviews, Vol. 68, No. 2, pp. 1106-1111.

NAE (2004). "The Engineer of 2020: Visions of Engineering in the New Century. National Academy of Engineering". Available at: https:/www.nap.edu/catalog/10999/theengineer-of-2020-visions-of-engineering-in-the-new_(accessed 20 September 2017).

Nasir, A.N.B.M.D., Ali, F.D., Noordin, N.K.B. and Noordin, M.S.B. (2011), “Technical skills and non-technical skills: predefinition concept", a paper presented at IETEC'11 Conference, 16-19 January 2011, Kuala Lumpur, Malaysia, available at : https://www.researchgate.net/publication/259782791_Technical_skills_and_nontechnical_skills_predefinition_concept (accessed 20 September 2017).

Othman, M.R., Hady, L., Repke, J.-U. and Wozny, G. (2012), "Introducing sustainability assessment and selection (SAS) into chemical engineering education”, Education for Chemical Engineers, Vol.7 No. 3, pp. 118-124.

Pegg, A., Waldock, J., Hendy-Isaac, S. and Lawton, R. (2012), "Pedagogy for employability”, The Higher Education Academy, York (UK). 
QS (2017), "World University Rankings by Subject 2016 - Engineering - Chemical”, available at: https://www.topuniversities.com/university-rankings/university-subject rankings/2016/engineering-chemical (accessed 20 September 2017).

Riley, D.M. (2015), "Pushing the Boundaries of Mass and Energy: Sustainability and Social Justice Integration in Core Engineering Science Courses" a paper presented at $122^{\text {nd }}$ ASEE Annual Conference and Exposition. June 14-17, 2015, Seattle, USA, available at: https://www.asee.org/public/conferences/56/papers/12743/download (accessed 20 September 2017).

Savelski, M J., Farrell, S. and Slater, C.S. (2013), "Sustainability Integrated throughout Rowan's Chemical Engineering Curriculum", a paper presented at Engineering Education for Sustainable Development, 22 - 25 September 2013, Cambridge, UK, available at: http://www-csd.eng.cam.ac.uk/proceedings-of-the-eesd13-conference cambridge-2013-v-2/eesd13-published-papers/savelski-m.pdf (accessed 20 September 2017).

Schaschke, C. (2014), A Dictionary of Chemical Engineering, Oxford University Press, Oxford, UK.

Scopus (2017), "Statistics for the search "life cycle assessment"", available at: https://www.scopus.com/home.uri (accessed 20 September 2017).

Taboada, H.A., Espiritu, J.F., Vazquez, A. and Moreno, O.C. (2011), “Experiences while incorporating sustainability engineering into the Industrial Engineering curricula" working paper, American Society for Engineering Education, Washington (USA).

The Guardian (2017), “Green business needs strong and stable support from the next UK government" $4^{\text {th }}$ June.

WCDE (1987), “Our Common Future”, Oxford University Press, Oxford (UK). 
Weber, N. R., Strobel, J., Dyehouse, M. A., Harris, C., David, R., Fang, J. and Hua, I. (2014), "First-Year Students' Environmental Awareness and Understanding of Environmental Sustainability Through a Life Cycle Assessment Module”, Journal of Engineering Education, Vol. 103 pp. 154-181.

Yorke, M. (2006), “Employability in higher education: what it is - what it is not". In Learning \& Employability Series 1. The Higher Education Academy, York, UK.

Yorke, M. and Knight, P. T. (2006), "Embedding employability into the curriculum", Learning \& Employability Series 1, The Higher Education Academy, York, UK.

\title{
Author Bios:
}

\section{Dr Alejandro Gallego-Schmid}

BSc (Hons), MEng, AMIChemE, PhD

\begin{abstract}
Alejandro has more than 10 years of experience as a sustainability expert. His professional experience has been focused on life cycle assessment (LCA), carbon footprint, circular economy, eco-design and global change. Nowadays Alejandro works as Research Associate at The University of Manchester, identifying sustainable solutions for industrial systems on a life cycle and eco-design basis, taking into account economic, environmental and social aspects and applying circular economy concepts. Alejandro also has experience in protected natural areas, solar heating, valorisation and recycling of waste, ceramics processing and environmental engineering in the industrial field.
\end{abstract}

\section{Dr Ximena C. Schmidt Rivera}

BSc. Eng. (Hons), MSc. Eng. (eq.), PhD 
Ximena is currently a Research Associate within the School of Chemical Engineering and Analytical Science, The University of Manchester. Since 2015, Ximena has worked within the Centre for Sustainable Energy Use in Food Chains (CSEF), where she specializes in the sustainability of different food products, their supply chains and alternative fuels, using life cycle assessment methodologies to assess environmental, economic and social aspects.

Prior to this, Ximena achieved first-class honors at Universidad de Santiago de Chile in Chemical Engineering (2007), worked as an engineering consultant before moving to Manchester to start her $\mathrm{PhD}$ in 2011.

\section{Dr Laurence Stamford}

MA (Oxon), $P h D$

Laurence is a Lecturer in Sustainable Chemical Engineering at The University of Manchester. His research focuses on the development and use of life cycle sustainability assessment, analysing the environmental, economic and social implications of technological systems from raw material extraction to disposal. Laurence's work spans energy, food and bio-processing and his teaching addresses sustainable development and renewable energy systems. His work has contributed to policy discussion at a national level, including via the Parliamentary Office of Science and Technology, Carbon Connect and the national media. 